\title{
BIOSIMILARS: OPPORTUNITIES, CHALLENGES, AND THE GENERAL PRINCIPLES GOVERNING THEIR DEVELOPMENT AROUND THE GLOBE
}

\author{
ISHITA KATHURIA ${ }^{1 *}$, VIKAS KUMAR SRIVASTAVA ${ }^{2}$
}

${ }^{1}$ Department of Pharmacy, School of Pharmaceutical Sciences, Delhi Pharmaceutical Sciences and Research University, New Delhi, Delhi, India. ${ }^{2}$ Department of Pharmaceutics, I.T.S Institute of Health and Allied Sciences (formerly I.T.S Paramedical College), Murad Nagar, Uttar Pradesh, India. Email: ishitakathuria02@gmail.com

Received: 02 September 2021, Revised and Accepted: 31 October 2021

\section{ABSTRACT}

Biologic drugs have revolutionized the treatment of many life-threatening and rare illnesses such as cancer and autoimmune diseases. Biologics are broadly referred as substances that are produced by living cells and are used in the treatment, prevention, or diagnosis of diseases. They include a wide range of substances, such as genetic material, antibodies, vaccines, or processes which act by influencing cellular processes that block disease or affect diseased cells. Biologics have become striking treatment options and the size of the market has grown hastily. It is expected that by 2023 , most of the patents will expire in the European Union opening a large potential market. Keeping this in mind, the ability to launch substitutes to original biologics, also known as biosimilars, presents many opportunities to generic companies. The field of biosimilars seems to be "breaking" the traditional division between the creations of innovative NCE-based medicines by research-based companies, on the one hand, and, on the other hand, mapping of these medicines by the generic companies. The field of biosimilars so far presents some considerable challenges, namely, regulatory, safety, economic, and legal which are still being debated and discussed in different forums. In this article, we have tried to summarize the general principles and regulations governing the development of biosimilars by regulatory authorities such as the World Health Organization, European Medicines Agency, US Food and Drug Administration, and Health Canada. Furthermore, we have tried to throw some light on the opportunities, challenges, and current scenarios pertaining to biosimilars.

Keywords: Biosimilars, Biologics, Regulatory Guideline, Food and Drug Administration, European Medicines Agency.

(C) 2021 The Authors. Published by Innovare Academic Sciences Pvt Ltd. This is an open access article under the CC BY license (http://creativecommons.org/ licenses/by/4.0/) DOI: http://dx.doi.org/10.22159/ijls.2021v9i6.43430. Journal homepage: https://innovareacademics.in/journals/index.php/ijls

\section{INTRODUCTION}

Biotechnology has coined the development of treatments for a variety of serious, rare, and severe diseases including cancers, heart attacks, stroke, multiple sclerosis, diabetes, rheumatoid arthritis, and autoimmune diseases. Numerous biological medicinal products have reached their expiration in the coming decade and with this expiry, similar biological medicinal products (SBMPs), or biosimilar medicinal products, "biosimilars" as they are now commonly called are being developed and a number of them are already available in different markets around the globe [1].

A biosimilar contains a version of the active substance of an already authorized original biological medicinal product (reference medicinal product [RMP]), demonstrates similarity to the RMP in terms of quality characteristics, biological activity, safety, and efficacy based on an inclusive comparability exercise [2].

There is a huge opportunity for the development of biosimilars in the near future because of the favoring adoption of regulatory guidelines by different countries. The specific product guidelines pertaining to biosimilars are also available and include filgrastim; epoetins; growth hormones; insulin; aloha-interferons; beta-interferons; monoclonal antibodies; follitropin; and low-molecular-weight heparins [3]. The United State Food Drug and Administration (FDA) evaluation of biosimilarity must reflect on the product's complexity, its formulation, its stability, and the efficacy of biochemical and functional characterizations and incorporate these factors into a risk-based approach. The understanding of the clinical effect of a biologic and the level of clinical information available on it will also affect the evaluation of risk, and the manufacturing processes may set up potential variants or impurities that could affect risk [4].
So far, the field of biosimilars presents several important challenges using safety, regulatory, legal, and economic which are the topics of discussion across the world [5].

\section{DEFINING BIOSIMILARS}

Different regulatory bodies have coined different definitions to describe the term "Biosimilars." Each regulatory body portrays a slight different perspective than the other which is quite evident through their definitions. Some of the definitions by the leaders in similar medicinal products are mentioned:

\section{World Health Organization (WHO)}

"A biotherapeutic product which is similar in terms of quality, safety, and efficacy to an already licensed reference biotherapeutic product" [6]

\section{US Food and Drug Administration (FDA)}

FDA defines "biosimilarity to mean that the biological product is highly similar to the reference product notwithstanding minor differences in clinically inactive components" and so on "there are no clinically meaningful differences between the biological product and the reference product in terms of the safety, purity, and potency of the product" [7]

\section{European Medicines Agency (EMA)}

A biosimilar medicine is a "biological medicine that is developed to be similar to an existing biological medicine." Biosimilars are not the same as generics, which have simpler chemical structures and are considered to be identical to their reference medicines. The active substance of a biosimilar and its reference medicine is essentially the same biological substance, though there may be minor differences due to their complex nature and production methods [8]. 
Therapeutic Goods Administration (TGA)

"A biosimilar or SBMP is a version of an already registered biological medicine that has a demonstrable similarity in physicochemical biological, and immunological characteristics, efficacy, and safety, based on comprehensive comparability studies [9]."

\section{Health Canada}

"A biosimilar biologic drug, or biosimilar, is a biologic drug that is highly similar to a biologic drug that was already authorized for sale. There are no expected clinically meaningful differences in efficacy and safety between a biosimilar and the biologic drug that was already authorized for sale [10]."

\section{AWAITING OPPORTUNITIES AND CURRENT SCENARIOS}

A very huge potential awaits the development of the biosimilars because the exclusive rights (patents and other data protection) for several biological medicinal products have reached their expiration and many more will expire in the coming decade. In the European Union (EU), by the year 2019, around 14 innovative biological products had been deprived of their market exclusivity as an orphan drug. By the end of 2029,34 other innovative biologics are ready to join them. It is expected that by 2023, most of the patents will expire in the EU opening a large potential market [11]. In the year 2026, the global biosimilars market is expected to reach approximately USD 44.7 billion from USD 15.6 billion (in 2021) in just a short span of 5 years at a $23.5 \%$ of CAGR. This market growth is driven by the increasing incidence of chronic diseases and the hope which lies in the similar medicinal products largely due to their cost-effectiveness and the short development span compared to the RMP. On an average, these products may employ $70 \%$ less cost and $30-50 \%$ less development time than their biologic originals saving almost $\$ 44$ billion health-care costs in the EU itself. The rising incidence of chronic diseases and cancer in the geriatric population was credited for the monoclonal antibodies segment gathering the largest share of $27.5 \%$ in the biosimilars market. The oncology segment is the largest due to which the cancer treatment is more accessible and affordable. The prevailing burden of cancer around the globe needs cost-effective treatment options which can be made accessible by the huge biosimilars market. This has led to increase in investments by major biological pharma companies in this domain of biosimilars. The growing markets include Africa, North America, Asia Pacific Latin America, Europe, and Middle East. Among all, the Asia-Pacific market is expected to be credited as the fastest-growing market during the period 2021-2026 due to the less stringent regulations, many emerging players and the increasing cooperation among regional and leading players for commercialization, manufacture, and development of biosimilars [12].

\section{DEVELOPING BIOSIMILARS}

Biotechnology uses living systems (plant or else animal cells, bacteria, viruses, and yeast) and modern technologies to generate biological medicines to treat diseases and genetic disorders in humans. Most of them, but not all biological medicines, are made using genetically modified cells. Each manufacturer has its own unique cell lines and develops its own proprietary (unique) manufacturing processes [13]. The production of biological medicines involves processes such as fermentation and purification. Even very small changes to these manufacturing processes like minor variations during production, for example, temperature variations, can result in considerable changes in the clinical properties of the biological medicine produced. It is very important to precisely control the manufacturing processes and the situation inside a production facility, to obtain consistent results and to assurance the safety and efficacy of the final product. The production of biological medicines is a complex process which requires a very high level of technical expertise with typically about 250 in-process tests being conducted compared to about 50 tests for a small molecule medicine [1].

\section{Characterization of Biosimilars}

To ensure assuring global quality, safety, and efficacy of biotherapeutics, the WHO provides globally accepted norms and standards for the evaluation of these products. Written standards established through the Expert Committee on Biological Standardization (ECBS) serve like a basis for setting national requirements for production, quality control, and overall regulation of biological medicines [7]. Comprehensive characterization of both Reference Biotherapeutic Product (RBP) and Similar Biotherapeutic Product (SBP) should be carried out using appropriate, biochemical, biophysical, and biological analytical techniques [14]. Below mentioned criteria shall be considered while conducting the comparability exercise:

\section{Physicochemical properties}

The physicochemical characterization ideally should include the determination of higher order (such as secondary/tertiary/quaternary) and primary structure using appropriate analytical methods (e.g., mass spectrometry and nuclear magnetic resonance) and other biophysical properties. Structural heterogeneity inherently occurs in proteins due to the biosynthesis process such as SBP and RBP which are likely to contain a mixture of these post-translationally modified forms. Appropriate efforts should be made to investigate, identify, and quantify these forms $[15,16]$.

\section{Biological activity}

Biological activity is the specific ability or capability of the product to achieve a defined biological effect. Biological assay reflects the mechanism of action of a protein and therefore serves as a bridge to clinical activity. A biological assay is a quality measure of the "function" of the protein product and can be used to determine whether a product variant has the appropriate level of activity (i.e., a product-related substance) or is inactive $[17,18]$

\section{Immunochemical properties}

Immunochemical properties confirm that the SBP is comparable to the RBP in terms of specificity, affinity, binding kinetics, and functional activity, where relevant [19].

\section{Impurities}

Due to the partial access to all necessary information on the manufacturing process in addition to the drug substance of the originator product, it is recognized that the evaluation of similarity of the impurity profiles between SBP and RBP will be generally difficult. Yet productrelated and process impurities should be identified, then quantified by biochemical and compared between the RBP and SBP. Some differences may be predictable because the proteins are produced by different manufacturing processes. If significant differences are observed in the impurity profile between the SBP and the RBP, their potential impact on efficacy and safety, including immunogenicity, must be evaluated $[20,21]$.

\section{Analytical techniques}

The methods should separate and analyze different variants of the product based on different underlying chemical, physical, and biological properties of protein molecules. For example, ion-exchange chromatography, isoelectric focusing, and capillary electrophoresis all separate proteins based on charge, but they act so under different conditions and based on different physicochemical properties. The parameters which evaluate biosimilars should be measured while making a determination of similarity between a SBP and a RBP, depicted in Table 1 [22,23].

\section{REGULATIONS AND PRINCIPLES GOVERNING BIOSIMILARS}

For the assessment of biosimilars, regulatory requirements from different regions such as the WHO, EU, US, and Asian Pacific Region are almost similar with specific guideline.

\section{WHO}

In the year 2007, the WHO formally recognized the need for overall regulation and the guidance for their evaluation. "Guidelines on 
Table 1: Parameters for the evaluation of biosimilars

\begin{tabular}{|c|c|c|}
\hline Parameters & Characteristics & Test for comparability \\
\hline \multirow[t]{7}{*}{ Physicochemical properties } & Primary structure & Edman degradation, peptide mapping with (LC-MS), \\
\hline & Secondary structure & C-terminal sequencing, Amino acid analysis. far UV, CD, \\
\hline & Tertiary and quaternary structure & NMR, FTIR, X-ray crystallography \\
\hline & Molecular mass & $\begin{array}{l}\text { Mass spectrometry - MALDI and ESI-MS, } \\
\text { ultracentrifugation, SDS-PAGE }\end{array}$ \\
\hline & Isoforms & Isoelectric focusing, capillary electrophoresis, IE-HPLC \\
\hline & Crystal structure & $\begin{array}{l}\text { Microscopy (where crystal structure is necessary for } \\
\text { action, e.g., protamine zinc insulin) }\end{array}$ \\
\hline & Sugar composition and linkage & $\begin{array}{l}\text { Quantitative monosaccharide analysis (for polysaccharide } \\
\text { biological medicines like heparin) }\end{array}$ \\
\hline \multirow{5}{*}{ Biological activity } & In vivo activity & Measuring therapeutic effect in animals \\
\hline & In vitro activity & $\begin{array}{l}\text { Cell proliferation or inhibition of proliferation, cell } \\
\text { senescence, and measurable changes in cell size or content } \\
\text { (e.g., mRNA) }\end{array}$ \\
\hline & Enzyme assays & Assay for potency \\
\hline & Receptor-binding assays & Assay for action \\
\hline & Chromogenic or turbidometric techniques & Promotion or inhibition of coagulation \\
\hline \multirow[t]{10}{*}{ Content, purity, and impurity profile } & Protein content & $\begin{array}{l}\text { Protein assay (e.g., Kjeldahl, Lowry, and Bradford), } \\
\text { Absorbance at } 280 \text { or } 230 \mathrm{~nm} \text {, HPLC, SDS-PAGE }\end{array}$ \\
\hline & Purity & $\begin{array}{l}\text { HPLC, RP-HPLC, size exclusion - HPLC, ion exchange - } \\
\text { HPLC, SDS-PAGE }\end{array}$ \\
\hline & Impurities - process derived & DNA - Threshold $®$ Host protein - [ELISA] \\
\hline & & Cell culture - ELISA \\
\hline & & Leachates - HPLC, GC \\
\hline & & Protein A-ELISA \\
\hline & Impurities - product derived & Oxidized - RP-HPLC \\
\hline & & Deamidated - RP-HPLC \\
\hline & & $\mathrm{N}$-terminal cyclisation - LC-MS \\
\hline & & Phosphorylation - IE-HPLC \\
\hline
\end{tabular}

NMR: Nuclear magnetic resonance, UV: Ultraviolet, CD: Circular dichroism, FTIR: Fourier transform infrared, MALDI: Matrix-assisted laser desorption ionization, ESI-MS: Electrospray ionization mass spectrometry, SDS-PAGE: Sodium dodecyl sulfate polyacrylamide gel electrophoresis, IE-HPLC: Ion exchange high-performance liquid chromatography, ELISA: Enzyme-linked immunosorbent assay

Evaluation of SBPs" were developed and adopted by the $60^{\text {th }}$ meeting of the WHO ECBS in 2009. The Annex 2 for the same guideline was also released by the Expert committee in its Sixtieth report in 2013 [24]. The guideline aims to provide globally acceptable principles for licensing SBPs that are claimed to be similar to the reference products (licensed before based on a full licensing dossier). The scope of the guidelines includes well-established and well-characterized biotherapeutic products that have been marketed for a suitable period of time with a proven quality, efficacy, and safety, such as recombinant DNA-derived therapeutic proteins. Manufacturers are required to submit a full quality dossier which includes a demonstration of robust and manufacture of the product, consistent complete characterization of the product, and the comparability exercise between the SBP and the RBP in the quality part, which together serve as the basis for the possible reduction in data requirement in the non-clinical and clinical development. The WHO guidelines on evaluating SBPs represent an important step forward in the global harmonization for the evaluation and regulation of biosimilar products, and provide clear guidance for both regulatory bodies and the pharmaceutical industry [25]. On March 1, 2016, draft guideline referred to as "Guideline on Evaluation of Monoclonal Antibodies as SBPs was released [26]. The outcome of which was then published in the WHO Technical Report Series, 2017, by the WHO ECBS in the $67^{\text {th }}$ report [27]. In the year 2019, the WHO prequalified its first biosimilar medicine known as trastuzumab which is a monoclonal antibody responsible for treating breast cancer in women [28].

\section{EU (EMA)}

The EU has pioneered in the development of a regulatory system for biosimilar products by approving the first biosimilar in the year 2006 . The EMA began formal consideration of scientific issues for biosimilar products as early as January 2001, then an ad hoc working group had discussed the comparability of medicinal products (that contains biotechnology derived proteins as active substances) [29]. In the year
2003, the European Commission had amended the provisions of the EU legislation governing requirements for marketing authorization applications (MAA) for medicinal products and ultimately established a new category of applications for "similar biological medicinal products [30]." In 2005, the EMA issued a general guideline on similar biological medicinal products, to introduce the concept of similar biological medicinal products, to outline the basic principles to be applied, and to provide applicants with a "user guide," showing where to find relevant scientific information [29,31]. The revised version of this guideline was first published in 2014 [2].

EU has taken an evidence-based and thoughtful approach, and has established a well-documented regulatory and legal pathway for the approval of biosimilar products different from the generic pathway. To grant a biosimilar product, the EMA requires justified and comprehensible comparability studies between the reference products and biosimilar on the non-clinical, quality, and clinical level, and is wellexplained in detail in the EMAguidelines. In the EU, the approval pathway of biosimilar products is based on the case-by-case reviews, due to the diversity and complexity of the biologic products. Therefore, besides the general guidelines, EMA also developed product class-specific guidelines on clinical and non-clinical studies. The approval pathway is now seen as one of the gold standards for authorizing biosimilar products among various countries. In the year 2006, the "Guideline on Similar Biological Medicinal Products Containing Biotechnologyderived Proteins as Active Substance: Quality Issues" was adopted by the CHMP, which addressed the requirements regarding the comparability exercises for quality, manufacturing processes, physicochemical characterization, purity, analytical methods, biological activity, and specifications of the similar biological medicinal product [32]. The revised version of this guideline was published in the year 2014 [15]. In 2011, EMA also issued a concept paper based on the revision of the guideline "Guideline on Similar Biological Medicinal Products 
Containing Biotechnology-derived Proteins as Active Substance: NonClinical and Clinical Issues [31,33]." The current effective version was released in 2015 [14].

\section{General principles governing the development of biosimilars in the EU [2]}

A biological medicinal product containing a version of the active ingredient of an already authorized biological medicinal product also known as the RMP. In European Economic Area (EEA), the MAA is granted authorization after the demonstration of similar nature of the two products, the chosen (RMP) and the biological medicinal product. Comparability studies play an important role in generating evidence conforming the similar nature in respect to efficacy, quality, biological activity, and safety of the chosen RMP and our similar biological medicinal product.

\section{Applying the biosimilar approach}

The success to developing a biosimilar relies solely on demonstrating similarity between the two products and generating similarity at the level of biological and physiochemical characteristics. The knowledge to interpret the differences between the RMP and the biological medicinal product is equally essential. It's the complexity of the biosimilars that it requires the comprehensive comparability (ICH Q5E) unlike the standard generic approach of demonstrating bioequivalence as in most chemically derived medicinal products. This approach is most likely to yield success in products that are highly purified and thus can be thoroughly characterized. The things that need to be taken care are as follows:

- Active ingredient of a biosimilar has to be similar in respect to biological and molecular characters to the chosen RMP

- Rout of administration and posology to be same as of the RMP

- If any deviations from the RMP are present in regard to pharmaceutical form, strength, formulation excipients, or presentation require proper justification. Additional data may be provided and no compromise should be made on safety

- Changes to improve efficacy are not too compatible with the biosimilar approach, however, still any differences that could have an advantage such as lower immunogenicity and levels of impurities (safety aspect) should be addressed but still may not preclude biosimilarity

- Once biosimilarity has been demonstrated in one indication, extrapolation can be used for other indications of RMP with proper justification

- No regulatory requirement to once again demonstrates the biosimilarity against the RMP once the MAA has been granted

- In regard to the quality data, biosimilars need to fulfill the requirements for Module 3 (defined in Annex 1 to Directive 2001/83/ EC). Furthermore, the technical requirements in the European Pharmacopeia and other requirements laid down in the CHMP and ICH guidelines need to be fulfilled

- All appropriate measures are required to be taken to clearly identify any biological medicinal product which can show adverse drug reaction with due regards to its batch number and brand name to support pharmacovigilance monitoring (Article 102(e) of Directive 2001/83/EC)

- Safety and efficacy comparable data of a biosimilar and chosen RMP have to be justified or demonstrated in accordance with requirements laid in Directive 2001/83/EC. Product-specific classes such as recombinant granulocyte-colony-stimulating factor [34], low molecular heparin [35], recombinant human insulin and its analogs [36], interferon beta [37], monoclonal antibodies [38], recombinant erythropoietins [25], recombinant follicle-stimulating hormone [39], and somatropin [40] have defined guidelines and can be referred. Apart from these products, the agency can be contacted for any other product query.

Choosing the RMP

The chosen RMP must be authorized in the EEA and should be used in the comparability studies of safety, quality, and efficacy during the development of biosimilar to generate coherent conclusions and data. In some cases, it may also be possible to compare the biosimilar in various in vivo non-clinical studies (wherever necessary) and clinical studies with a non-EEA authorized comparator (adequate data to scientifically justify and establish a bridge to the EEA authorized RMP) only if the product is authorized by the regulatory authority with a similar regulatory and scientific standard as that of the EMA (e.g., ICH countries).The bridging data would include data from analytical studies comparing all the three products, namely, EEA authorized RMP, non-EEA authorized RMP, and the biological medicinal product. It may also include data from studies such as clinical PK and/or PD bridging studies for the three products. The acceptability decision will be taken case by case and is recommended to be discussed with the regulatory agency. The final decision will still be made during the assessment of the application at the time of submission. Furthermore, it is the responsibility of the applicant to establish the comparability between both the EEA authorized RMP and the non-EEA authorized RMP.

Demonstration of biosimilar quality comparability studies, side-byside analysis of biosimilar product from the site to commercial scale with EEA authorized RMP is necessary required. For the development of Quality Target Product Profile, combined use of EEA authorized and non-EEA authorized RMP is acceptable.

Principles to establish the biosimilarity

Any difference observed in the physiochemical and biological characteristics of the chosen RMP and biological medicinal products and their potential impact on the efficacy and safety should be duly justified.

The stepwise approach is adapted initiating with the comprehensive characterization of biological and physiochemical properties. Further, the nature and extent of the clinical studies and non-clinical in vivo studies would depend on the evidences obtained while the robustness of biological, physiochemical, and non-clinical in vitro characterization was being performed. Clinical studies are performed to address the slight variability at the previous steps and confirm the comparability clinical performances of the chosen RMP and our similar medicinal product, however, clinical data can never be used to justify the substantial differences between the two products at the level of quality.

The comparability studies need to be sensitive in regards to conduct, design, population, and/or endpoints to detect any relevant differences between the RMP and biosimilar. In specific cases, where the similar safety and efficacy can be deduced from the biological activity/potency, physiochemical characteristics, and PK and/or PD profiles, clinical trials are not mandatory. Here, the nature of excipients and clinical trials should not give rise to any potential concerns. It is advisable to discuss such approaches with the regulatory agencies.

In cases where the biosimilar comparability exercise shows that relevant differences between the RMP and intended biosimilar making it unlikely that the intended biosimilar will be established eventually, therefore, a stand-alone development for supporting a full MAA should be considered instead.

The biosimilar products approved in the EU by EMA in the year 2021 are depicted in Table 2.

\section{Australia (TGA)}

International regulators such as the TGA directly apply the principles that are laid down by the EU legislation for the approval and development of biosimilars. TGA directly refers to the already released guidelines by EU for different aspects such as quality, clinical and nonclinical studies, establishing comparability and for different products, and their specific guidelines [49].

\section{US (FDA)}

Approval of follow-on biologics in the US based on the current regulations depends on whether the biologic product is licensed under 
Table 2: List of EMA approved biosimilar for the year 2021 [41]

\begin{tabular}{|c|c|c|c|c|c|c|c|c|}
\hline $\begin{array}{l}\text { Marketing } \\
\text { authorization } \\
\text { date }\end{array}$ & $\begin{array}{l}\text { Product } \\
\text { number }\end{array}$ & $\begin{array}{l}\text { Marketing } \\
\text { authorization } \\
\text { holder/ } \\
\text { company } \\
\text { name }\end{array}$ & $\begin{array}{l}\text { Medicine } \\
\text { name }\end{array}$ & $\begin{array}{l}\text { International } \\
\text { non-proprietary } \\
\text { name (INN)/ } \\
\text { common name }\end{array}$ & Strength & $\begin{array}{l}\text { Pharmaceutical } \\
\text { form }\end{array}$ & $\begin{array}{l}\text { Route of } \\
\text { administration }\end{array}$ & Pack size \\
\hline $\begin{array}{l}\text { January 11, } \\
2021\end{array}$ & $\begin{array}{l}\text { EMEA/ } \\
\mathrm{H} / \mathrm{C} / 005640\end{array}$ & $\begin{array}{l}\text { Samsung } \\
\text { Bioepis NL B.V. }\end{array}$ & $\begin{array}{l}\text { Onbevzi } \\
{[42]}\end{array}$ & Bevacizumab & $25 \mathrm{mg} / \mathrm{mL}$ & $\begin{array}{l}\text { Concentrate } \\
\text { for solution for } \\
\text { infusion }\end{array}$ & $\begin{array}{l}\text { Intravenous } \\
\text { use }\end{array}$ & $\begin{array}{l}4 \mathrm{~mL} \text { in } 1 \text { vial } \\
16 \mathrm{~mL} \text { in } 1 \text { vial }\end{array}$ \\
\hline $\begin{array}{l}\text { February 5, } \\
2021\end{array}$ & $\begin{array}{l}\text { EMEA/ } \\
\text { H/C/004965 }\end{array}$ & $\begin{array}{l}\text { Mylan Ireland } \\
\text { Limited }\end{array}$ & $\begin{array}{l}\text { Kirsty } \\
\text { [43] }\end{array}$ & Insulin aspart & $100 \mathrm{U} / \mathrm{mL}$ & $\begin{array}{l}\text { Solution for } \\
\text { injection }\end{array}$ & $\begin{array}{l}\text { Subcutaneous } \\
\text { use or } \\
\text { intravenous }\end{array}$ & $\begin{array}{l}10 \mathrm{~mL} \text { in } 1 \text { vial } \\
10 \mathrm{~mL} \text { in } 5 \text { vials } \\
10 \mathrm{~mL} 5 \\
(5 \times 1) \text { vials } \\
\text { (multipack) } \\
3 \mathrm{~mL} \text { in } 1 \\
\text { pre-filled pen } \\
3 \mathrm{~mL} \text { in } 5 \\
\text { pre-filled pens } \\
3 \text { mL in } 10(2 \times 5) \\
\text { pre-filled pens } \\
\text { (multipack) }\end{array}$ \\
\hline $\begin{array}{l}\text { February 11, } \\
2021\end{array}$ & $\begin{array}{l}\text { EMEA/ } \\
\text { H/C/005188 }\end{array}$ & $\begin{array}{l}\text { Celltrion } \\
\text { Healthcare } \\
\text { Hungary Kft. }\end{array}$ & $\begin{array}{l}\text { Yuflyma } \\
\text { [44] }\end{array}$ & adalimumab & $\begin{array}{l}40 \mathrm{mg} / \\
0.4 \mathrm{~mL}\end{array}$ & $\begin{array}{l}\text { Solution for } \\
\text { injection }\end{array}$ & $\begin{array}{l}\text { Subcutaneous } \\
\text { use }\end{array}$ & $\begin{array}{l}6 \text { PFS with } \\
\text { needle guard+6 } \\
\text { alcohol pads } \\
6 \text { pre-filled } \\
\text { pens+6 alcohol } \\
\text { pads }\end{array}$ \\
\hline $\begin{array}{l}\text { March 26, } \\
2021\end{array}$ & $\begin{array}{l}\text { EMEA/ } \\
\text { H/C/005286 }\end{array}$ & $\begin{array}{l}\text { Mabxience } \\
\text { Research SL }\end{array}$ & $\begin{array}{l}\text { Alymsys } \\
{[45]}\end{array}$ & bevacizumab & $25 \mathrm{mg} / \mathrm{mL}$ & $\begin{array}{l}\text { Concentrate } \\
\text { for solution for } \\
\text { infusion }\end{array}$ & $\begin{array}{l}\text { Intravenous } \\
\text { use }\end{array}$ & $\begin{array}{l}4 \mathrm{~mL} \text { in } 1 \text { vial } \\
16 \mathrm{~mL} \text { in } 1 \text { vial }\end{array}$ \\
\hline $\begin{array}{l}\text { March 26, } \\
2021\end{array}$ & $\begin{array}{l}\text { EMEA/ } \\
\text { H/C/005556 }\end{array}$ & $\begin{array}{l}\text { STADA } \\
\text { Arzneimittel } \\
\text { AG }\end{array}$ & $\begin{array}{l}\text { Oyavas } \\
{[46]}\end{array}$ & bevacizumab & $25 \mathrm{mg} / \mathrm{mL}$ & $\begin{array}{l}\text { Concentrate } \\
\text { for solution for } \\
\text { infusion }\end{array}$ & $\begin{array}{l}\text { Intravenous } \\
\text { use }\end{array}$ & $\begin{array}{l}4 \mathrm{~mL} \text { in } 1 \text { vial } \\
16 \mathrm{~mL} \text { in } 1 \text { vial }\end{array}$ \\
\hline April 21, 2021 & $\begin{array}{l}\text { EMEA/ } \\
\text { H/C/005327 }\end{array}$ & $\begin{array}{l}\text { Mylan IRE } \\
\text { Healthcare } \\
\text { Limited }\end{array}$ & $\begin{array}{l}\text { Abevmy } \\
\text { [47] }\end{array}$ & bevacizumab & $25 \mathrm{mg} / \mathrm{mL}$ & $\begin{array}{l}\text { Concentrate } \\
\text { for solution for } \\
\text { infusion }\end{array}$ & $\begin{array}{l}\text { Intravenous } \\
\text { use }\end{array}$ & $\begin{array}{l}4 \mathrm{~mL} \text { in } 1 \text { vial } \\
4 \mathrm{~mL} \text { in } 5 \text { vials } \\
16 \mathrm{~mL} \text { in } 1 \text { vial } \\
16 \mathrm{~mL} \text { in } 2 \text { vials } \\
16 \mathrm{~mL} \text { in } 3 \text { vials }\end{array}$ \\
\hline $\begin{array}{l}\text { August 18, } \\
2021\end{array}$ & $\begin{array}{l}\text { EMEA/ } \\
\text { H/C/005545 }\end{array}$ & $\begin{array}{l}\text { Samsung } \\
\text { Bioepis NL B.V }\end{array}$ & $\begin{array}{l}\text { Byooviz } \\
{[48]}\end{array}$ & ranibizumab & $10 \mathrm{mg} / \mathrm{mL}$ & $\begin{array}{l}\text { Solution } \\
\text { injection }\end{array}$ & Intravitreal use & $\begin{array}{l}1 \text { vial+1 filter } \\
\text { needle+1 } \\
\text { injection needle }\end{array}$ \\
\hline
\end{tabular}

the United States Public Health Service Act or approved under the United States Food, Drug, and Cosmetic Act. For those biologic drugs marketed under the PHS Act, the BPCI Act passed by the US Congress on March 23, 2010, amends the PHS Act to establish an abbreviated approval pathway for biological products which are interchangeable or highly similar with a FDA authorized biologic drug while giving FDA the authority to approve follow-on biologics under the section $351(\mathrm{k})$ of the PHS Act [50].

FDA has established three committees to ensure consistency in the FDA's regulatory approach of follow-on biologics. The committees are the Center for Biologics Evaluation and Research (CBER)/Center for Drug Evaluation and Research (CDER), Biosimilar Implementation Committee, CBER Biosimilar Review Committee (BRC), and the CDER BRC. The CDER/CBER BRC will focus on the cross-center policy issues related to the implementation of the BPCI Act. The CDER BRC and CBER BRC are responsible for considering requests of applicants for advice about proposed development programs for biosimilar products, reviewing Biologic License Applications (BLAs) that are submitted under the 351(k) section of the PHS Act, and managing related issues. Thus, the review process steps of CDER BRC and CBER BRC include: (1) Applicant submits request for advice, (2) internal review team meeting, (3) internal CDER BRC (CBER BRC) meeting, (4) internal post-BRC meeting, and (5) applicant meeting with CDER (CBER) [7].
General principles governing the development of biosimilars in the US [51-58]

Biological products are regulated by the FDA and are used to prevent, diagnose, cure, and treat medical conditions and diseases. All the biological products approved by FDA, including biosimilar, interchangeable, and reference products, undergo a rigorous assessment to ensure their safety, efficacy, and quality for patient use. A single biological product which is already approved by FDA and against which a proposed biosimilar product can be compared is referred to as reference product. A reference product receives approval in a "standalone" application and it must contain all information and data necessary to demonstrate its effectiveness and safety. The data necessary to demonstrate the effectiveness and safety of a reference product will generally also include clinical trials for the indications being sought by the applicant/manufacturer.

Applying the biosimilar approach

Biosimilar is highly similar to and does not possess any clinically meaningful differences in purity, safety, and potency (effectiveness and safety) from, an existing reference product already approved by FDA. The aim of a biosimilar development program is to establish while demonstrating biosimilarity between the reference product and the proposed biosimilar product and, not just independently establish the effectiveness and safety of the proposed product. This generally includes data from: 
- Analytical studies to demonstrate that the proposed biological product is highly similar to the FDA-approved reference product, nevertheless the minute differences in clinically inactive components

- Animal studies which would also include an assessment of toxicity

- Clinical study or studies that are sufficient to demonstrate potency, safety, and purity of the biosimilar product for one or more of the disease indications for which the reference product is already licensed. Typically includes pharmacokinetic (PK), immunogenicity, and sometimes pharmacodynamic (PD) assessment. It may include a comparative clinical study too.

Apart from the data listed above, an interchangeable product application must be submitted including data or information demonstrating that:

- The same clinical results are expected as that of the reference product to be demonstrated in the proposed interchangeable product in any given patient

- A product which is administered more than once to a patient, switching between the reference product and the proposed interchangeable product does not decrease effectiveness or increase safety risks in comparison to using just the reference product without any such switching between products.

Choosing the reference product

A single biological product which is already approved by FDA and against which a proposed biosimilar product can be compared is referred to as reference product. It is approved based on, among other things, a full complement of effectiveness and safety data. A proposed biosimilar product is evaluated and compared against a reference product to ensure the high similarity and no clinically meaningful differences.
Principles to establish the biosimilarity

The applicant/manufacturer of a proposed biosimilar product is responsible for generating a set of data comparing the proposed product to the approved reference product to demonstrate biosimilarity.

- The comparative data are evaluated and generated in a stepwise manner that begins with detailed analytical (functional and structural) comparison and characterization of the products, followed by the animal studies if necessary and then move on to the comparative clinical studies

- Subsequently, rather than producing the same full profile of clinical and non-clinical data as that of the reference product, an applicant/ manufacturer which shows its biosimilar product has no clinically meaningful differences and is highly similar to the approved reference product, might also rely in part on FDA's former determination of effectiveness and safety for the approval of reference product. Implying that biosimilar manufacturers do not need to perform as many lengthy and expensive clinical trials, possibly leading to a faster access to approval of these products, reduced costs for patients and additional therapeutic options

- FDA assesses each biosimilar on a case-to-case basis to determine which data are required to establish biosimilarity and which elements can be waived off if deemed scientifically fitting.

Many other factors can help alter the data requirements for different biosimilar applications like:

- The robustness and strength of the comparative analytical studies that show similar functions and structure between the reference product and the proposed biosimilar. For instance, analytical similarity data displaying very minor analytical differences might provide a strong support and reflect that the product is highly similar

Table 3: List of FDA approved biosimilar and interchangeable products for the year 2020 and 2021 [59]

\begin{tabular}{|c|c|c|c|c|c|c|c|c|}
\hline $\begin{array}{l}\text { Date } \\
\text { approval }\end{array}$ & BLA number & Applicant & $\begin{array}{l}\text { Proprietary } \\
\text { name }\end{array}$ & Proper name & Strength & $\begin{array}{l}\text { Dosage } \\
\text { Form }\end{array}$ & $\begin{array}{l}\text { Route of } \\
\text { Administration }\end{array}$ & $\begin{array}{l}\text { Product } \\
\text { Presentation }\end{array}$ \\
\hline $\begin{array}{l}\text { March 20, } \\
2020\end{array}$ & $\begin{array}{c}761,100 \\
\text { (biosimilar) }\end{array}$ & $\begin{array}{l}\text { Samsung } \\
\text { Bioepis Co., Ltd. }\end{array}$ & $\begin{array}{l}\text { Ontruzant } \\
{[60]}\end{array}$ & Trastuzumab-dttb & $420 \mathrm{mg}$ & $\begin{array}{l}\text { For } \\
\text { injection }\end{array}$ & Intravenous & $\begin{array}{l}\text { Single-dose } \\
\text { vial }\end{array}$ \\
\hline $\begin{array}{l}\text { June 10, } \\
2020\end{array}$ & $\begin{array}{c}761,111 \\
\text { (biosimilar) }\end{array}$ & $\begin{array}{l}\text { Hospira Inc., a } \\
\text { Pfizer Company }\end{array}$ & $\begin{array}{l}\text { Nyvepria } \\
{[61]}\end{array}$ & Pegfilgrastim-apgf & $\begin{array}{l}6 \mathrm{mg} / 0.6 \\
\mathrm{~mL}\end{array}$ & Injection & Subcutaneous & $\begin{array}{l}\text { Pre-filled } \\
\text { syringe }\end{array}$ \\
\hline $\begin{array}{l}\text { June } 30, \\
2020\end{array}$ & $\begin{array}{c}125,545 \\
\text { (biosimilar) }\end{array}$ & $\begin{array}{l}\text { Hospira Inc., a } \\
\text { Pfizer Company }\end{array}$ & Retacrit [62] & Epoetin alpha-epbx & $\begin{array}{l}20,000 \\
\text { units/mL; } \\
20,000 \\
\text { Units/2 mL } \\
(10,000 \\
\text { Units/mL) }\end{array}$ & Injection & $\begin{array}{l}\text { Intravenous, } \\
\text { subcutaneous }\end{array}$ & $\begin{array}{l}\text { Multi-dose } \\
\text { vial }\end{array}$ \\
\hline $\begin{array}{l}\text { July 6, } \\
2020\end{array}$ & $\begin{array}{c}761,154 \\
\text { (biosimilar) }\end{array}$ & $\begin{array}{l}\text { Mylan } \\
\text { Pharmaceuticals } \\
\text { Inc. }\end{array}$ & Hulio [63] & Adalimumab-fkjp & $\begin{array}{l}40 \mathrm{mg} / 0.8 \\
\mathrm{~mL} ; 20 \\
\mathrm{mg} / 0.4 \mathrm{~mL}\end{array}$ & Injection & Subcutaneous & $\begin{array}{l}\text { Autoinjector } \\
\text { and pre-filled } \\
\text { syringe; } \\
\text { pre-filled } \\
\text { syringe }\end{array}$ \\
\hline $\begin{array}{l}\text { November } \\
30,2020\end{array}$ & $\begin{array}{c}761,081 \\
\text { (biosimilar) }\end{array}$ & $\begin{array}{l}\text { Pfizer Ireland } \\
\text { Pharmaceuticals }\end{array}$ & $\begin{array}{l}\text { Trazimera } \\
{[64]}\end{array}$ & Trastuzumab-qyyp & $150 \mathrm{mg}$ & $\begin{array}{l}\text { For } \\
\text { injection }\end{array}$ & Intravenous & $\begin{array}{l}\text { Single-dose } \\
\text { vial }\end{array}$ \\
\hline $\begin{array}{l}\text { December } \\
17,2020\end{array}$ & $\begin{array}{c}761,140 \\
\text { (biosimilar) }\end{array}$ & Amgen, Inc. & Riabni [65] & Rituximab-arrx & $\begin{array}{l}100 \mathrm{mg} / 10 \\
\mathrm{~mL}(10 \mathrm{mg} / \\
\mathrm{mL}) ; 500 \\
\mathrm{mg} / 50 \mathrm{~mL} \\
(10 \mathrm{mg} / \\
\mathrm{mL})\end{array}$ & Injection & Intravenous & $\begin{array}{l}\text { Single-dose } \\
\text { vial }\end{array}$ \\
\hline $\begin{array}{l}\text { July } 28, \\
2021\end{array}$ & $\begin{array}{c}761,201 \\
\text { (interchangeable) }\end{array}$ & $\begin{array}{l}\text { Mylan } \\
\text { Pharmaceuticals } \\
\text { Inc. }\end{array}$ & $\begin{array}{l}\text { Semglee } \\
{[66]}\end{array}$ & $\begin{array}{l}\text { Insulin } \\
\text { glargine-yfgn }\end{array}$ & $\begin{array}{l}1000 \\
\text { units } / 10 \\
\text { mL }(100 \\
\text { Units/mL); } \\
300 \text { units/3 } \\
\text { mL (100 } \\
\text { units/mL) }\end{array}$ & Injection & Subcutaneous & $\begin{array}{l}\text { Multidose vial; } \\
\text { autoinjector }\end{array}$ \\
\hline $\begin{array}{l}\text { September } \\
17,2021\end{array}$ & $\begin{array}{l}761,202 \\
\text { (biosimilar) }\end{array}$ & $\begin{array}{l}\text { Samsung } \\
\text { Bioepis Co., Ltd. }\end{array}$ & Byooviz [67] & Ranibizumab-nuna & $10 \mathrm{mg} / \mathrm{mL}$ & Injection & Intravitreal & $\begin{array}{l}\text { Single-dose } \\
\text { vial }\end{array}$ \\
\hline
\end{tabular}

BLA: Biologic License Application 
Table 4: Requirements to develop biosimilars in different region

\begin{tabular}{|c|c|c|c|c|c|}
\hline Requirement & WHO & EU & Canada & Japan & Korea \\
\hline Term & SBPs & Biosimilars & SEBs & FOBs & Biosimilars \\
\hline Scope & \multicolumn{5}{|c|}{ Recombinant protein drugs } \\
\hline Efficacy & \multicolumn{5}{|c|}{ Comparability margins should be justified and pre-specified } \\
\hline Reference product & \multicolumn{5}{|c|}{ Authorized in same region if not then jurisdiction with well established regulatory framework } \\
\hline Stability & \multicolumn{5}{|c|}{ Stress conditions and accelerated } \\
\hline Purity & \multicolumn{5}{|c|}{ Product-related and process-related impurities } \\
\hline Manufacture & \multicolumn{5}{|c|}{ Manufacture and full chemistry data package } \\
\hline Biological activity & \multicolumn{5}{|c|}{ Quantitative measure (e.g., enzymatic or binding assays) and qualitative (function) } \\
\hline Non-clinical studies & \multicolumn{5}{|c|}{$\begin{array}{l}\text { In vitro (e.g., receptor-binding, cell-based assays), in vivo (pharmacodynamics activity, at least one repeat } \\
\text { dose toxicity study, antibody measurements, local tolerance) }\end{array}$} \\
\hline PK study and criteria & \multicolumn{5}{|c|}{ Single-dose, steady-state studies, or repeated determination of PK, Traditional $80-125 \%$ equivalence range } \\
\hline & \multicolumn{5}{|c|}{ Comparative PK/PD studies with selected pharmacodynamics markers } \\
\hline Safety & \multicolumn{5}{|c|}{ Risk management plan and pre-licensing safety data } \\
\hline
\end{tabular}

SBP: Similar Biotherapeutic Product

- How similar the PD and PK profiles are between the reference product and the proposed biosimilar

- Pre-existing information regarding the safety profile of the FDAapproved reference product. For instance, if it is known that patients might develop immune responses with the reference product, FDA will require a more rigorous assessment of immune responses for the biosimilar too.

The biosimilar and interchangeable products approved in the US by FDA in the year 2020 and 2021 are depicted in Table 3.

\section{Canada (Health Canada)}

The federal regulatory authority of Canada, the Health Canada evaluates the efficacy, safety, and quality of drugs available in Canada. It also recognizes it with the expiration of patents for biologic drugs as the manufacturers may be interested in pursuing consequent entry versions of these biologic drugs, which are called Subsequent Entry Biologics (SEB) in Canada. In the year 2010, Health Canada issued the "Guidance for Sponsors: Information and Submission Requirements for Subsequent Entry Biologics (SEBs)," the objective of which was to provide guidance on how to satisfy the regulatory requirements in Canada under the Food and Drugs Act and Regulations for the authorization of SEB [10]. The key principles that are used by Health Canada to evaluate the similar medicinal product/biosimilar align with other regulatory agencies as that of EMA, FDA, and the WHO [68].

The harmonized scope and requirements across different markets are depicted in Table 4.

\section{CHALLENGES AHEAD}

Biosimilars complex development presents challenges at every next level, from analytical assays demonstrating comparability to selection of a manufacturing platform, to clinical testing and in vivo testing, post-marketing surveillance, and even market access. One of the challenges for the development of such assays is the procurement of high-quality assay reagents, such as target antigens or coating antibodies. In some cases, the assays performed by the originator company may be unknown, antiquated, or even patent protected. Another major challenge is the significance of the glycosylation state of the biosimilar in comparison to the reference product. This ultimately can have a major impact on the similarity of calibration curves of the biosimilar and reference product. The glycosylation state of a biosimilar can be influenced by many different steps in the production process used to generate a given molecule, for example, cell culture conditions, and manufacturing or finishing processes. Some other challenges that were revealed in a recent WHO survey (2019-2020) are the lack of resources, insufficient/unavailable reference products in any country, difficulties with practice of naming of biosimilars and interchangeability, and the problem with the quality of biosimilars [69-71].

\section{CONCLUSION}

The biologics have rekindled hope in the treatment of various rare and life-threatening diseases such as cancer and autoimmune diseases. With the patent expiration going to take place for many products in the coming years, the market for their substitutes also known as biosimilars continues to grow opening a whole new domain. Compared to the NCE-based drugs, the development of similar medicinal product is complex and requires specific guidelines ensuring safety and efficacy of the biosimilars. The regulatory pathway used for the approval of biosimilars by regulatory health authorities must address the characteristics of biosimilars that discriminate them from generic drugs, or more broadly, the way in which biologics differ from NCEbased drugs,therefore, these regulatory bodies around the globe have devised various policies for the same. Both general and the productspecific guidelines have been established by the WHO, FDA, EMA, TGA, and Health Canada while some take reference from the already developed guidelines some have formulated their own versions to select research sites strategically to optimize overall development timelines and achieve registration goals. The challenges such as lack of resources, unavailable reference product, quality issues, and selecting the manufacturing site are still to be addressed. Looking toward the future, there is a trend toward harmonization of reference product requirements and an era of opportunities.

\section{REFERENCES}

1. European Commission. What You Need to Know about Biosimilar Medicinal Products. A Consensus Information Document; 2014. p. 1-43. Available from: https://www.ec.europa.eu/docsroom/documents/8242/ attachments/1/translations/en/renditions/pdf

2. European Medicines Agency. Guideline on Similar Biological Medicinal Products. CHMP/437/04, Revision 1; 2014. p. 1-7. Available from: https://www.ema.europa.eu/en/documents/scientific-guideline/ guideline-similar-biological-medicinal-products-rev1 en.pdf

3. European Medicines Agency. Multidisciplinary: Biosimilar; 2021. Available from: https://www.ema.europa.eu/en/human-regulatory/ research-development/scientific-guidelines/multidisciplinary/ multidisciplinary-biosimilar [Last accessed on 2021 Oct 21].

4. Kozlowski S, Woodcock J, Midthun K, Sherman RB. Developing the nation's biosimilars program. N Engl J Med 2011;365:385-8.

5. Chu R, Pugatch DM. Biogenerics or Biosimilars? Discussing the Present, Considering the Future. The Stockholm Network; 2009. Available from: https://www.yumpu.com/en/document/view/32210375/biogenerics-orbiosimilars-the-stockholm-network [Last accessed on 2021 Oct 21].

6. World Health Organization. WHO Informal Consultation on International Nonproprietary Names (INN) Policy for Biosimilar Products; 2006. Available from: https://cdn.who.int/media/docs/defaultsource/international-nonproprietary-names-(inn)/biosimilarsinn-report. pdf?sfvrsn=b936f 65 f $4 \&$ download=true

7. US Food and Drug Administration. Scientific Considerations in Demonstrating Biosimilarity to a Reference Product Guidance for Industry Scientific Considerations in Demonstrating Biosimilarity to a 
Reference Product. Quality Considerations in Demonstrating; 2015.

8. EMEA. Procedure for European Union Guidelines and Related Documents Within the Pharmaceutical Legislative Framework, Communication; 2009. p. 1-16.

9. Evaluation of Biosimilars: What is a Biosimilar? Therapeutic Goods Administration (TGA); 2021. Available from: https://www.tga.gov.au/ book-page/what-biosimilar [Last accessed on 2021 Oct 22].

10. Guidance Document: Information and Submission Requirements for Biosimilar Biologic Drugs; 2021. Available from: https:/www. canada.ca/en/health-canada/services/drugs-health-products/biologicsradiopharmaceuticals-genetic-therapies/applications-submissions/ guidance-documents/information-submission-requirements-biosimilarbiologic-drugs-1.html [Last accessed on 2021 Oct 21].

11. Piloting a Route to the Biosimilars Opportunities in EuropePMLiVE; 2021. Available from: http://www.pmlive.com/pharma intelligence/piloting_a_route_to_the_biosimilars_opportunities_in_ europe 1371282 [Last accessed on 2021 Oct 21].

12. Biosimilars Market by Product, Indication, Region-Global Forecast to 2026; 2021. Available from: https://www.reportlinker.com/p04604343/ Biosimilars-market-by-product-manufacturing-application-globalforecast-to.html?utm_source=gnw) [Last accessed on 2021 Oct 21].

13. Troein $\mathrm{P}$, Newton $\mathrm{M}, \overline{\mathrm{S}} \mathrm{S}$ ott $\mathrm{K}$. The Impact of Biosimilar Competition in Europe; 2020. Available from: https://www.ec.europa.eu/health/sites default/files/human-use/docs/biosimilar_competition_en.pdf

14. European Medicines Agency. Guidēine on Similar Biological Medicinal Products Containing Biotechnology-Derived Proteins as Active Substance: Non-Clinical and Clinical Issues. EMEA/CHMP/ BMWP/42832/2005, Revision 1; 2014. Available from: https:/www. ema.europa.eu/en/documents/scientific-guideline/guideline-similarbiological-medicinal-products-containing-biotechnology-derivedproteins-active en-2.pdf

15. European medicines Agency. Guideline on Similar Biological Medicinal Products Containing Biotechnology-Derived Proteins as Active Substance: Quality Issues (Revision 1), EMA/CHMP/ BWP/247713/2012; 2014. Available from: https://www.ema.europa. eu/en/documents/scientific-guideline/guideline-similar-biologicalmedicinal-products-containing-biotechnology-derived-proteinsactive en- 0. pdf

16. Chow SC, Liu JP. Desing and Analysis of Bioavailability and Bioequivalence Studies. $3^{\text {rd }}$ ed. London, United Kingdom: Chapman and Hall, CRC; 2008. p. 733.

17. Combe C, Tredree RL, Schellekens H. Biosimilar epoetins: an analysis based on recently implemented European medicines evaluation agency guidelines on comparability of biopharmaceutical proteins. Pharmacotherapy 2005;25:954-62.

18. World Health Organization. Guidelines on Evaluation of Similar Biotherapeutic Products (SBPs). Geneva: World Health Organization; 2009

19. Porter S. Human immune response to recombinant human proteins J Pharm Sci 2001;90:1-11.

20. PMDA. Pharmaceuticals and Medical Devices Agency. Guidelines for the Quality, Safety and Efficacy Assurance of Follow-on Biologics; 2009. p. 1-23. Available from: https://www.pmda.go.jp/ files/000153851.pdf

21. Rambourg P. Pharmaceutical evaluation of biosimilars: Important differences from generic low-molecular-weight pharmaceuticals. Eur J Hosp Pharm 2021;11:11-7. Available from: https://www.academia. edu/2155071/pharmaceutical evaluation of biosimilars important differences_from_generic_low_molecular__weight_pharmaceuticals [Last accessed on 2021 Oct 22].

22. Chirino AJ, Mire-Sluis A. Characterizing biological products and assessing comparability following manufacturing changes. Nat Biotechnol 2004;22:1383-91.

23. Evaluation of Biosimilars: Appendix 1-Suggested Techniques for Inclusion in Comparability Studies, Therapeutic Goods Administration (TGA); 2021. Available from: https://www.tga.gov.au/book-page/ appendix-1-suggested-techniques-inclusion-comparability-studies [Last accessed on 2021 Oct 23].

24. World Health Organization. Annex 2. Guidelines on Evaluation of Similar Biotherapeutic Products (SBPs). Geneva: World Health Organization; 2013. Available from: https://www.who.int/biologicals/ publications/trs/areas/biological therapeutics/trs 977 annex 2.pdf

25. European Medicines Agency. Guideline on Non-Clinical and Clinical Development of Similar Biological Medicinal Products Containing Recombinant Erythropoietins, EMEA/CHMP/BMWP/301636/2008, Revision 1; 2018. Available from: http://www.ema.europa.eu

26. World Health Organization. Guidelines on Evaluation of Monoclonal
Antibodies as Similar Biotherapeutic Products (SBPs). Geneva: World Health Organization; 2016. Available from: https://www.who.int/ biologicals/mab_1st_draft_kg_ik_1_march_2016_clean.pdf

27. World Health Organization. Annex 2. Guidelines on Evaluation of Monoclonal Antibodies as Similar Biotherapeutic Products (SBPs). Geneva: World Health Organization; 2017. Available from: https:// www.who.int/biologicals/biotherapeutics/who trs 1004 web annex_2.pdf?ua=1

28. World Health Organization. WHO Prequalifies First Biosimilar Medicine to Increase Worldwide Access to Life-Saving Breast Cance Treatment. Geneva: World Health Organization; 2021. Available from https://www.who.int/news/item/18-12-2019-who-prequalifies-firstbiosimilar-medicine-to-increase-worldwide-access-to-life-savingbreast-cancer-treatment [Last accessed on 2021 Oct 24].

29. European Medicines Agency. Guideline On Similar Biological Medicinal Products. CHMP/437/04; 2005. Available from: https:/ www.ema.europa.eu/en/documents/scientific-guideline/guidelinesimilar-biological-medicinal-products-first-version_en.pdf

30. Official Journal of the European Union. Commission Directive 2003/63/EC,L159/46;2003. Available from: http:/www.eur-lex.europa. eu/lexuriserv/lexuriserv.do?uri=oj: 1:2003:159:0046:0094:en: pdf

31. Eropean Medicines Agency. Concept Paper on the Revision of the Guideline on Similar Biological Medicinal Products Containing Biotechnology-derived Proteins as Active Substance: Non-Clinical and Clinical Issues, EMA/CHMP/BMWP/572828/2011; 2011.

32. European Medicines Agency. Guideline on Similar Biological Medicinal Products Containing Biotecnology-Derived Proteins as Active Substance: Quality Issues, EMEA/CHMP/BWP/49348/2005; 2006. Available from: http://www.ema.europa.eu/docs/en_gb/ document_library/scientific_guideline/2009/09/wc500003953.pdf

33. European Medicines Agency. Concept Paper on the Revision of the Guideline on Similar Biological Medicinal Product, EMA/CHMP/ BMWP/572643/2011; 2011 .

34. European Medicines Agency. Guidance on Similar Medicinal Products Containing Recombinant Granulocyte-Colony Stimulating Factor, EMEA/CHMP/BMWP/31329/2005; 2006. Available from: https://www.ema.europa.eu/en/documents/scientific-guideline/ annex-guideline-similar-biological-medicinal-products-containingbiotechnology-derived-proteins en.pdf

35. European Medicines Agency. Guideline on Non-Clinical and Clinical Development of Similar Biological Medicinal Products Containing Long-Molecular-Weight-Heparins. EMEA/CHMP/ BMWP/118264/2007, Revision 1; 2016

36. European Medicines Agency. Guideline on Non-Clinical and Clinical Development of Similar Biological Medicinal Products Containing Recombinant Human Insulin and Insulin Analogues, EMEA/CHMP/ BMWP/32775/2005, Revision 1; 2015.

37. European Medicines Agency. Guideline on Similar Biological Medicinal Products Containing Interferon Beta, EMA/CHMP/ BMWP/652000/2010; 2013 .

38. European Medicines Agency. Guideline on Similar Biological Medicinal Products Containing Monoclonal Antibodies-Non-Clinical and Clinica Issues, EMA/CHMP/BMWP/403543/2010; 2012. Available from: http://www.liebertonline.com/doi/abs/10.1089/blr.2011.9970

39. European Medicines Agency. Guideline on Non-Clinical and Clinical Development of Similar Biological Medicinal Products Containing Recombinant Human Follicle Stimulating Hormone (r-hFSH), EMA/ CHMP/BMWP/671292/2010; 2013.

40. European Medicines Agency. Guideline on Similar Medicinal Products Containing Somatropin, EMEA/CHMP/BMWP/94528/2005, Revision 1; 2018. Available from: https://www.ema.europa.eu/en documents/scientific-guideline/annex-guideline-similar-biologicalmedicinal-products-containing-biotechnology-derived-proteins en-1.pdf

41. European Medicines Agency; 2021. Available from: https://www.ema. europa.eu/en [Last accessed on 2021 Oct 24].

42. Onbevzi, European Medicines Agency; 2021. Available from: https:// www.ema.europa.eu/en/medicines/human/epar/onbevzi [Last accessed on 2021 Oct 28].

43. Kirsty (Previously Kixelle), European Medicines Agency; 2021 Available from: https://www.ema.europa.eu/en/medicines/human/epar/ kirsty-previously-kixelle [Last accessed on 2021 Oct 28].

44. Yuflyma, European Medicines Agency; 2021. Available from: https:// www.ema.europa.eu/en/medicines/human/epar/yuflyma [Last accessed on 2021 Oct 28].

45. Alymsys, European Medicines Agency; 2021. Available from: https:// www.ema.europa.eu/en/medicines/human/epar/alymsys [Last accessed on 2021 Oct 28]. 
46. Oyavas, European Medicines Agency; 2021. Available from: https:// www.ema.europa.eu/en/medicines/human/epar/oyavas [Last accessed on 2021 Oct 28].

47. Abevmy, European Medicines Agency; 2021. Available from: https:// www.ema.europa.eu/en/medicines/human/epar/abevmy [Last accessed on 2021 Oct 28].

48. Byooviz, European Medicines Agency; 2021. Available from: https:// www.ema.europa.eu/en/medicines/human/epar/byooviz [Last accessed on 2021 Oct 28].

49. Therapeutic Goods Administration, Biosimilar Medicines Regulation, Version 2.2; 2018. Available from: https:/www.tga.gov.au/sites/ default/files/biosimilar-medicines-regulation.pdf

50. US Food and Drug Administration. Quality Considerations in Demonstrating Biosimilarity of a Therapeutic Protein Product to a Reference Product Guidance; 2015. Available from: https://www.fda. gov/media/135612/download

51. Biosimilar and Interchangeable Products, FDA; 2021. Available from: https://www.fda.gov/drugs/biosimilars/biosimilar-and-interchangeableproducts [Last accessed on 2021 Oct 24]

52. Biosimilar Development, Review, and Approval, FDA; 2021. Available from: https://www.fda.gov/drugs/biosimilars/biosimilar-developmentreview-and-approval [Last accessed on 2021 Oct 24].

53. Patient Materials, FDA; 2021. Available from: https://www.fda.gov/ drugs/biosimilars/patient-materials [Last accessed on 2021 Oct 24]

54. Health Care Provider Materials, FDA; 2021. Available from: https:// www.fda.gov/drugs/biosimilars/health-care-provider-materials [Last accessed on 2021 Oct 24]

55. Webinars, Presentations, and Articles, FDA; 2021. Available from: https://www.fda.gov/drugs/biosimilars/webinars-presentations-andarticles [Last accessed on 2021 Oct 24].

56. Industry Information and Guidance, FDA; 2021. Available from: https://www.fda.gov/drugs/biosimilars/industry-information-andguidance [Last accessed on 2021 Oct 24].

57. Biosimilar Product Information, FDA; 2021. Available from: https:// www.fda.gov/drugs/biosimilars/biosimilar-product-information [Last accessed on 2021 Oct 24].

58. Prescribing Biosimilar and Interchangeable Products, FDA; 2021 Available from: https://www.fda.gov/drugs/biosimilars/prescribingbiosimilar-and-interchangeable-products [Last accessed on 2021 Oct 24]

59. FDA Purplebook; 2021. Available from: https://purplebooksearch.fda gov [Last accessed on 2021 Oct 24]

60. Ontruzant: Purple Book Product Details; 2021. Available from: https://purplebooksearch.fda.gov/productdetails?query $=761100 \quad$ [Last accessed on 2021 Oct 28].

61. Nyvepria: Purple Book Product Details; 2021. Available from https://purplebooksearch.fda.gov/productdetails?query=761111 [Last accessed on 2021 Oct 28]

62. Retacrit: Purple Book Product Details; 2021. Available from: https:/ purplebooksearch.fda.gov/productdetails?query $=125545 \quad$ [Last accessed on 2021 Oct 28].

63. Hulio: Purple Book Product Details; 2021. Available from: https:/ purplebooksearch.fda.gov/productdetails?query $=761154 \quad$ [Las accessed on 2021 Oct 28]

64. Trazimera: Purple Book Product Details; 2021. Available from: https://purplebooksearch.fda.gov/productdetails?query=761081 [Last accessed on 2021 Oct 28]

65. Riabni: Purple Book Product Details; 2021. Available from: https:/ purplebooksearch.fda.gov/productdetails?query $=761140$ [Last accessed on 2021 Oct 28]

66. Semglee: Purple Book Product Details; 2021. Available from: https:// purplebooksearch.fda.gov/productdetails?query $=761201$ [Last accessed on 2021 Oct 28].

67. Byooviz: Purple Book Product Details; 2021. Available from: https:// purplebooksearch.fda.gov/productdetails?query $=761202$ [Last accessed on 2021 Oct 28].

68. Health Canada. Biosimilar Biologic Drugs in Canada; 2019. p. 1-10. Available from: https://www.canada.ca/content/dam/hc-sc/migration/ hc-sc/dhp-mps/alt formats/pdf/brgtherap/applic-demande/guides/ factsheet-en-2019-08-23.pdf

69. Kang HN, Thorpe R, Knezevic I, Casas Levano M, Chilufya MB Chirachanakul P, et al. Regulatory challenges with biosimilars: An update from 20 countries. Ann NY Acad Sci 2021;1491:42-59.

70. Opportunities and Challenges in Biosimilar DevelopmentBioProcess International BioProcess International; 2021. Available from: https:/www.bioprocessintl.com/manufacturing/biosimilars/ opportunities-challenges-biosimilar-development [Last accessed on 2021 Oct 24].

71. Top Challenges Facing Biosimilar Adoption, Manufacturing; 2021 Available from: https://www.pharmanewsintel.com/news/topchallenges-facing-biosimilar-adoption-manufacturing [Last accessed on 2021 Oct 24]. 